\title{
Recent updates on the economic use of poly hydroxy butyrate (PHB): A green alternative to plastics
}

\author{
Mukesh R. Jangra ${ }^{1}$, Ikball ${ }^{1}$ K. S. Nehra ${ }^{2}$, Sumit Jangra ${ }^{1 *}$ Amit Pippal ${ }^{1}$ and Virendra K. Sikka ${ }^{1}$ \\ ${ }^{1}$ Department of Molecular biology, Biotechnology \& Bioinformatics CCS Haryana Agricultural University, \\ Hisar, Haryana, India-125004 \\ ${ }^{2}$ Department of Biotechnology, Govt. College Hisar, 125001
}

\begin{abstract}
Excessive uses of polymer plastics in boundless spheres have resulted in waste accumulation. There is an urgent need for switching over to compostable and biodegradable plastics that too from renewable resources. Polyhydroxybutyrate (PHB) is a unique biopolymer which is biodegradable and most close to plastics which is miscible with the conventional plastic. The adaptation and commercialization of PHB depend upon its ready availability in a pocketfriendly manner. The following presentation attempts to discuss economic strategies to reduce the production costs of PHB as well as its expeditious production from Agri-byproducts and its applications in various fields. Various sources like microorganisms, genetically modified bacteria, plants and different methods are being looked into, so that quality, quantity and financial side of PHB production can be controlled. It is presented here that PHB production is a natural capability of microbes exploited recently. This potential in the form of new technology is contributing to fulfil the need of plastic along with the environmental beauty and cleanliness. Novel bacterial fermentation strategies of polyhydroxybutyrate production, for improved productivity and quality of PHB for commercial production are summarized here.
\end{abstract}

KEY WORDS: PHB; RENEWABLE RESOURCES; BIOPLASTICS; PHB-PRODUCING BACTERIA AND BIOSYNTHESIS

\author{
ARTICLE INFORMATION: \\ *Corresponding Author: sumit.jangra712@gmail.com \\ Received $19^{\text {th }}$ Jan, 2018




\section{INTRODUCTION}

The demand of plastics is increasing with the increasing population and synthetic plastics provide a range of utilities in the civilization of mankind, at the same time accumulation of these non-degradable plastics in the environment is a menacing drawback. Plastic is a synthetic polymer with several advantages because its structure can be operated chemically to have varied shape and durability. But microbes in the environment are not able to degrade plastic because of chemical complexity and large molecular size (Atlas \&t Bartha, 1993, Andrady, 1994; Zheng et al., 2005; Mueller, 2006; Tokiwa et al., 2009, Andrady, 2015; Barth et al., 2016; Wei et al., 2017).

Recently, plastic industries of many countries are taking interest in the replacement of non-biodegradable by degradable plastics so that environmental issues can be fixed. Because of resistant and elastic in nature, bioplastics are used in various studies, disposable commodities and as a packing material. The most studied is polyhydroxybutyrate (PHB), an eco-friendly, green plastic and a striking alternative to petrochemical plastic. Although lots of outlooks have been tied up with bioplastic but a lot has to be improved to make it commercially available. Most important among all is cost feasibility and a production cycle or the time taken by the bacteria for PHB production (Grothe, 1999; Gurieff, 2007; Cesário, 2014; Haas 2015). So, there is an urgent need to develop a cost effective and expeditious protocol for maximization of PHB production. With the advancement of science, it is suggested that this trouble can be swamped by using natural substrates like molasses and simple production procedures rather going for complex ones. This article reviews brief introduction about PHB and novel fermentation strategies for isolation and screening of efficient and important PHB producing strains. Also, some explanation about tools and technique for PHB optimization and identification are given. After that, molecular characterization of PHB genes is described. The present communication Present communication reviews the application, future trends and expression of PHB in alternative host.

Polyhydroxybutyrate (PHB), a family of bio polyesters with diverse structures, is the only bio plastics completely synthesized by microorganisms. These are natural, thermoplastic, aliphatic biopolyesters that completely meet the terms like bio based, biodegradable, compostable or biocompatible to qualify them as Green plastics. All bioplastics have a unique property of being completely degraded to $\mathrm{CO}_{2}$ and $\mathrm{H}_{2} \mathrm{O}$ by PHA hydrolases and PHA depolymerases (Jendrossek \& Handrick 2002; Choi et al., 2004). PHA production is mainly based on renewable resources (Braunegg et al., 2004, Bharti \&
Shweta 2016; Chandani, 2018). Agricultural biproducts are used for fermentative PHA production (Gasser et al., 2009; Hamiesh et al., 2015; Getachew \&t Woldesenbet 2016). Biosynthesis and degradation of PHA is entirely attuned to carbon cycle (fig. 1). These are the only polymer plastic miscible and industry compatible products which do not necessitate the creation of any additional machining capabilities.

\section{STRUCTURE OF POLYHYDROXYBUTYRATE (PHB)}

Polyhydroxyalkanoates (polyesters) are formed by linear polymerization of hydroxy acyl units. The 2-, 3-, 4-, 5- or 6- hydroxy acidsjoin to form homo-polymers or copolymers (Chen, 2010). On the basis of number of carbon atoms present in the monomeric form of polyhydroxyalkanoates (PHAs) these are classified as short chain, medium chain ( 3 to 5 carbon atoms) and long chain (6 or more) PHAs (Pan and Inoue, 2009). The third main class of $\mathrm{P}(3 \mathrm{HA})$ s is the SCL/MCL-P(3HA)s, which is a copolymers made up of SCL and MCL-3HA monomers consisting of 3-14 carbons. LCL-PHAs have properties in between the SCL-P(3HA)s and MCL-P(3HA)s dependent on the mole ratio of SCL to MCL monomers, but the nature and proportion of these monomers are being influenced by the type and relative quantity of carbon sources supplied to the growth media. In spite of a large number of polyhydroxyalkanoatepolymers, only a few of them are employed for large scale production which includes: $\mathrm{P}(3 \mathrm{HB})$; poly-(3-hydroxybutyrate-co-3 hydroxyvalerate) and poly-3-hydroxybutyrate-co-3-hydroxy hexanoate (Asrar \& Gruys, 2002; Chanprateep, 2010; Chandani, 2018).

\section{POLYHYDROXYBUTYRATE PRODUCER}

Microorganisms, as well as transgenic plants, are used for PHB production (fig. 2). Among the more than 250 different natural PHA-producers, only a few bacteria have been engaged for the biosynthesis of PHB. They include hydrocarbon degraders, halophiles, photosynthetic bacteria, plant growth promoting bacteria etc. as shown in fig. 2. C. necator has been the most extensively studied and commonly used bacterium for PHB production. Imperial Chemical Industries (ICI plc) firstly used this bacterial strain for the production of PHBV copolymer with a trade name was Biopol. In recent times, Metabolix Inc. (USA) obtained the Biopol patents. For industrial purpose, it is wanted to grow strains that can attain high final cell density in short period of time and high PHB production from undemanding and inexpensive substrates. Thus, genetic engineering serves as a powerful tool in the development of microbial strains that can produce PHA from cheap renew- 


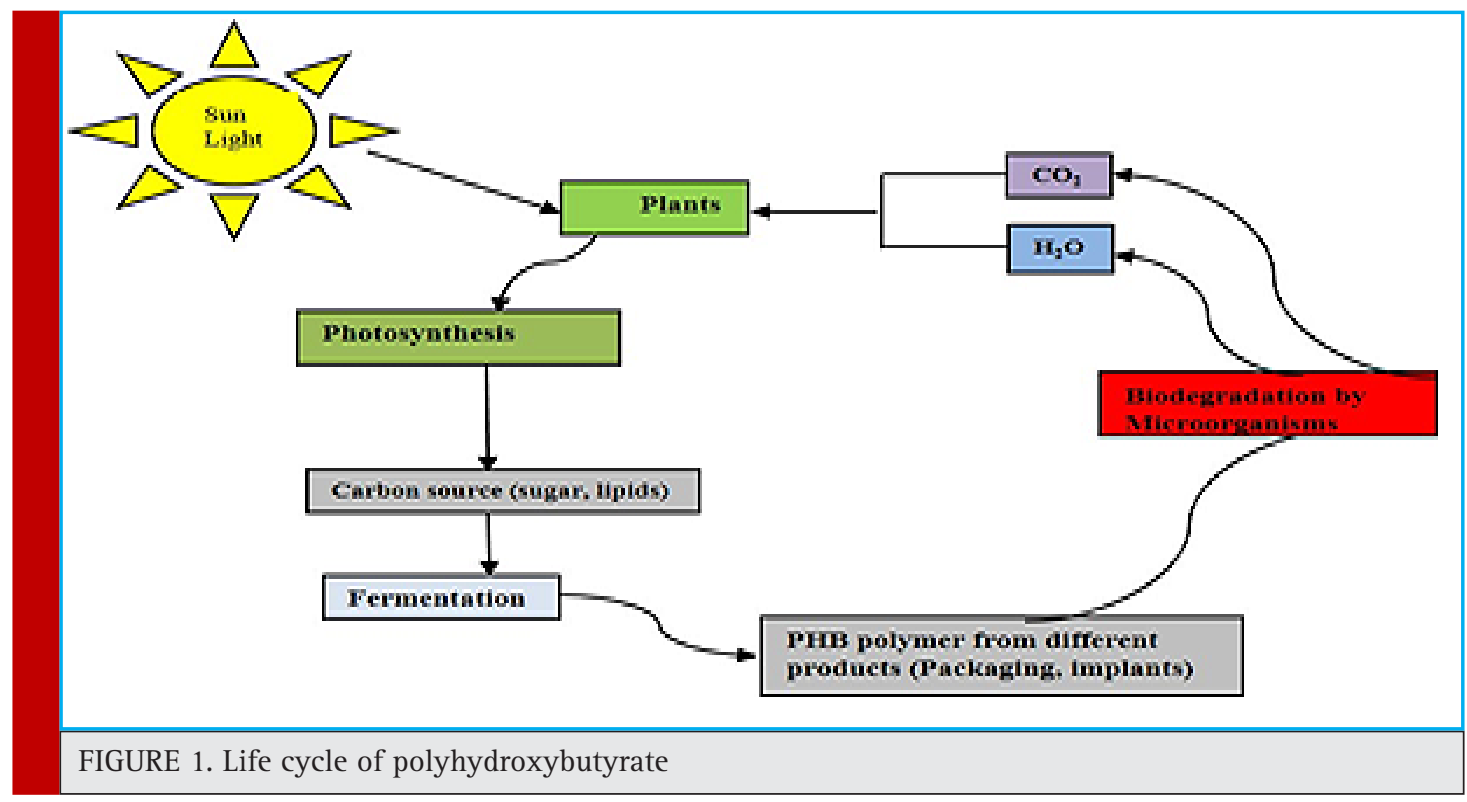

able resources efficiently. Transgenic plants are also very good alternative host for the production of PHB. But nowadays, the research on halophilic bacteria for PHB production has attracted scientist because these bacteria have advantage of unsterile and continuous fermentation process. However, few reports have been published to explore the potential of PHB production using marine bacteria and seawater as nutrient sources (Liu et al., 2016).

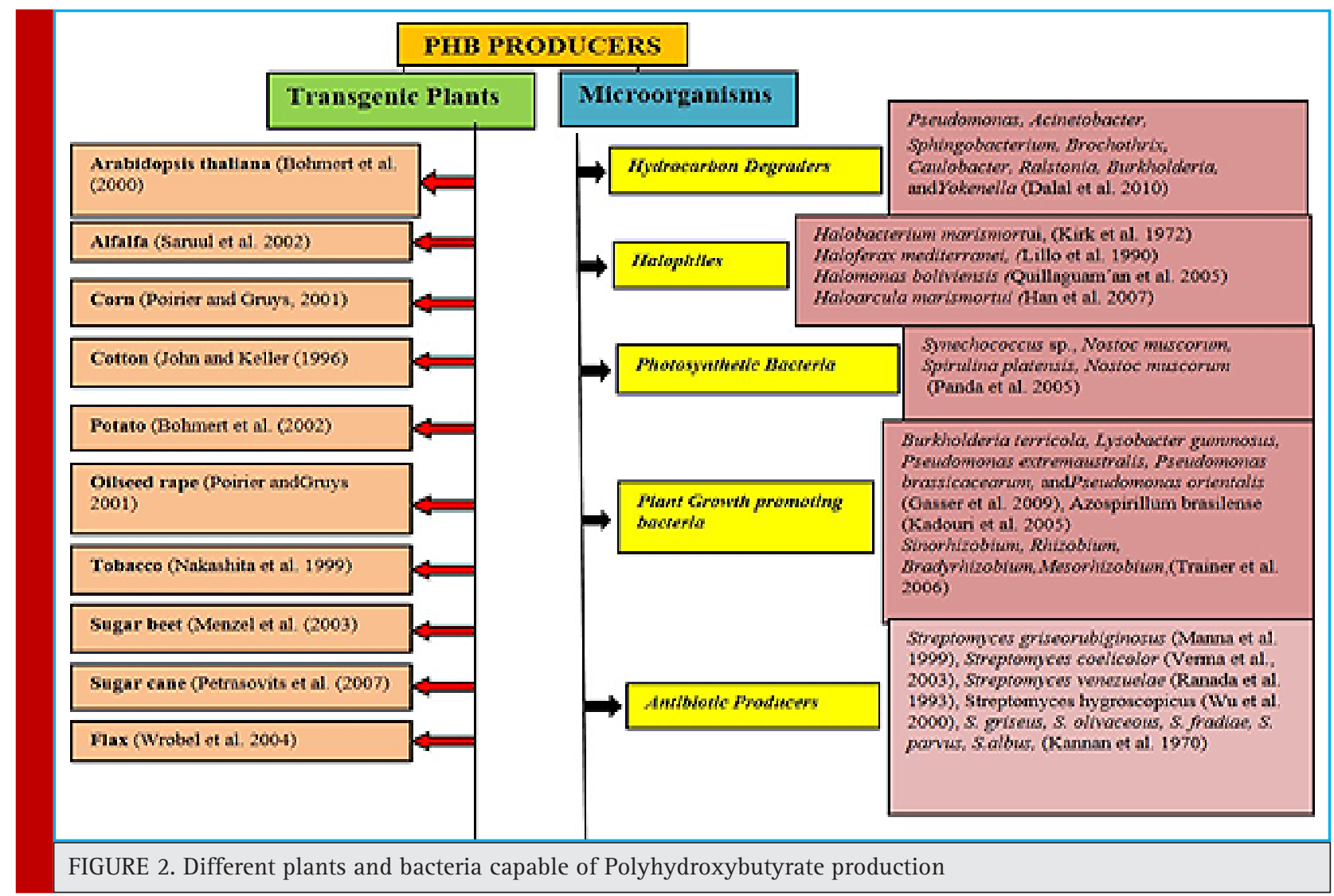




\section{GENERAL PROPERTIES OF PHB}

PHB a poly-3-hydroxybutyric acid homo-polymer has a melting point of $179{ }^{\circ} \mathrm{C}$ and is extremely crystalline $(80 \%)$ in nature. Temperature above melting point leads to degradation of PHB. Some of the properties of PHB are similar to polypropylene with three unique characteristics: thermoplastic process ability, complete water resistance and complete biodegradability (Hrabak, 1992). General properties of PHB are: water insoluble, relatively resistant to hydrolytic degradation, good oxygen permeability, resistant to UV, susceptible to acids and bases, soluble in chlorinated hydrocarbons including chloroform, non-toxic, biocompatible, high tensile strength (40MPa), sinks in water facilitating anaerobic biodegradation and less sticky when melted making it potentially good material for clothing in future. PHA polymers with different subunit compositions and hence different physical and thermal properties can be tailormade using novel PHA synthase for specific applications (Sharma et al., 2017)P. putida LS46123, was able to synthesize polyhydroxyalkanoate (PHA.

\section{IMPORTANCE OF PHB TO MICROBES}

PHB is very important for microbes. Under nutrient stress, intracellular accumulation of PHB accumulates up to a level of as high as $90 \%$ of the dry cell weight (Madison \& Huisman 1999). When the availability of nutrient sources like nitrogen and phosphorus is less and carbon is in excess, PHB acts as energy storage house. PHB act as a redox regulator within the cell and in some bacteria like Ralstonia eutropha and Rhodospirillum rubrum, it is involved in pyridine nucleotide dependent reduction of acetoacetyl-CoA. (Senior \&t Dawes, 1973; Steinbüchel, 1991). Encystment of Azotobacter cells is also associated with PHB accumulation. During starvation, presence of PHB protects the cellular components like RNA and proteins (Vinet \& Zhedanov 2010) and it plays an important role in sporulation. Obruca et al., (2016which permits unrestricted use, distribution, and reproduction in any medium, provided the original author and source are credited.Accumulation of polyhydroxybutyrate (PHB) investigation suggested the potential protective mechanisms of PHB when bacterial cells are exposed to freezing and thawing. Pavez et al., (2009) studied that PHAs apply a protective effect against freezing in Sphingopyxis chilensis. Several PHA-producing bacterial strains have also been isolated from Antarctic freshwater and Antarctic soil which indicates that PHA accumulation is a common metabolic strategy adopted by many bacteria to deal with cold environments and other stresses (Galia, 2010; Nielsen et al., 2017) (fig. 3).

\section{GENES AND ENZYMES INVOLVED IN BACTERIAL PHB SYNTHESIS PATHWAY}

Different genes are involved in PHA biosynthesis in various pathways and in some bacteria, they occur together as clusters. The organization of the genes involved in PHA biosynthesis is varied among the organisms and the difference in gene organization makes the different PHA operon. Molecular genetic studies have expanded the knowledge available since 1987 about the various metabolic, biochemical and physiological processes taking place in PHB synthesis. Various microorganisms have been characterized depending upon the genes and enzymes they utilize for PHB synthesis and degradation. Now it is clear that several pathways for PHB formation have been evolved by nature according to the requirements of a particular niche. Three different enzymes are involved in PHB biosynthesis pathway (fig. 4). New phaC genes that encode PHA synthase enzymes, produce PHAs with novel monomer compositions, have been isolated from different bacteria in various environments (Sasidharan et al., 2016; Ling et al., 2011; Ng \& Sudesh, 2016)Malaysia. It is a rod-shaped, gram-negative bacterium with high sequence identity (99\%. DNA extracted from a soil microbial community was used to construct metagenomic libraries, which were then screened for novel phaC genes (Cheng et al., 2014).

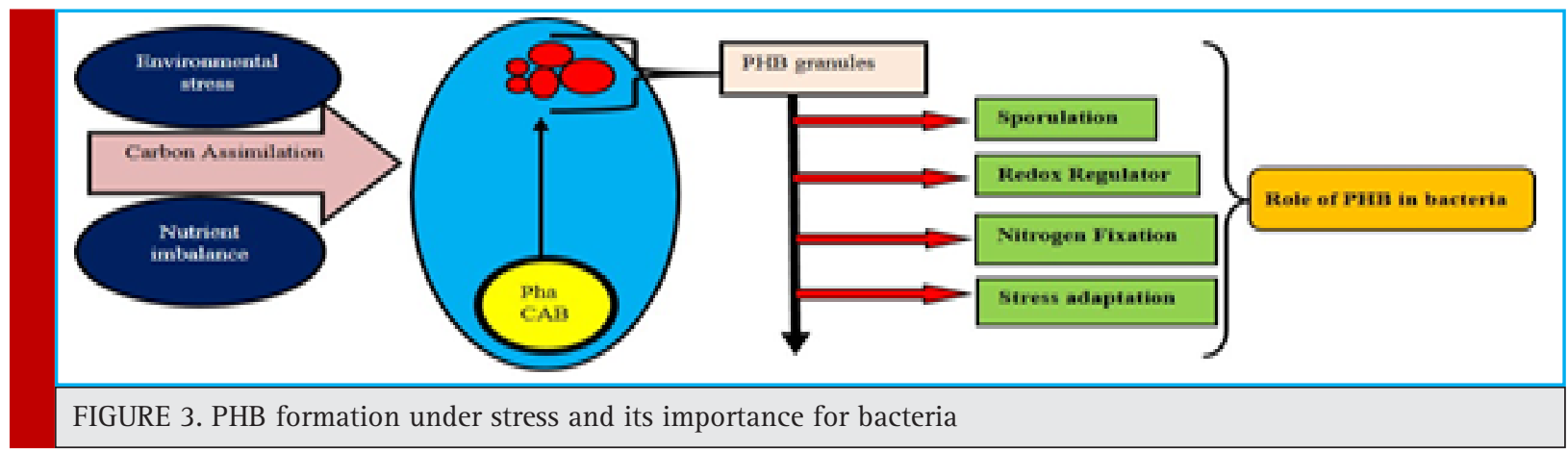




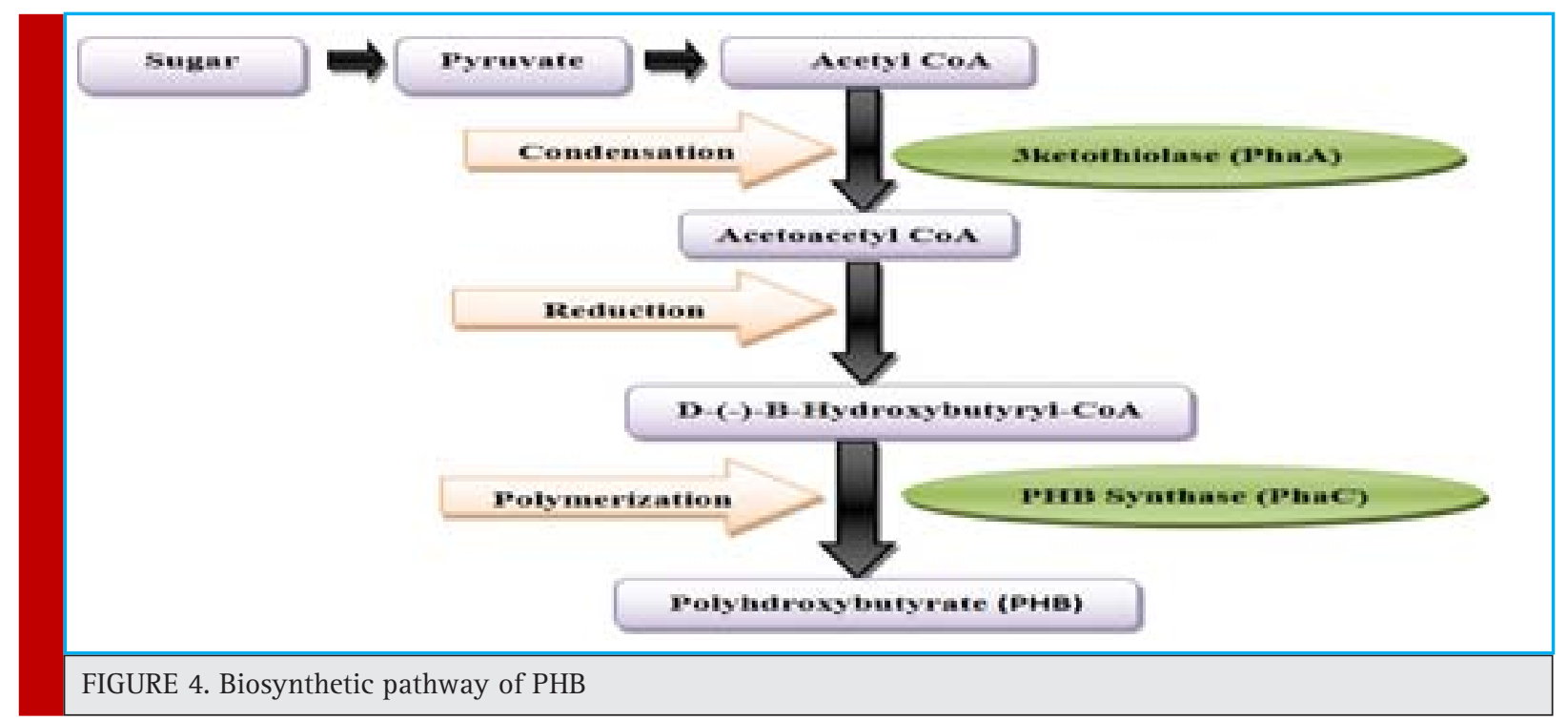

\section{SCREENING AND IDENTIFICATION METHODS FOR PHB ACCUMULATION IN BACTERIA}

Screening of a broad collection of bacteria in short period is very crucial. Several methods given below are on hand for screening the PHB producing bacteria. Staining and microscopic visualization methods include the use of different stains like Sudan Black $B$ and Nile Blue A, specific for detecting PHB granules. For the rapid screening, viable colony staining technique has been recommended. Sudan black B was first advocated by Hartman (1940), for use as bacterial fat stain. Later on, Burdon revised the procedure for identifying bacterial intracellular fat in 1942. They prepared Sudan B stained bacterial slides, counterstained with safranin but it is considered as the preliminary test. Ostle \&t Holt, (1982) and Spiekermann et al., (1999) suggested another procedure.

Nielsen et al., (2010) studied a combination of fluorescence in situ hybridization (FISH), with staining techniques for cell viability, PHB accumulation and polyphosphate in microorganisms. A number of Spectrophotometric and analytical methods have been developed to determine the PHB content in the microbial cells. A method developed by Williamson \&t Wilkinson, (1958) measures the turbidity of PHB produced by the digestion of microbial cells with sodium hypochlorite solution. Jüttner et al., (1975) told about Infrared Spectroscopy which is based on the information that the PHB molecule gives a strong carbonyl absorption peak at $1728 \mathrm{~cm}^{-1}$ in the infrared spectrum. PHB is extracted from dried cells with chloroform and its content determined from the absorbance of carbonyl bond. Hong et al., (1999) introduced Fourier transform infrared spectroscopy (FTIR) which is a speedy method for detecting bacterial polyhydroxybutyrate in intact cells. Ion-exclusion high-pressure liquid chromatography (HPLC) was used by Karr et al., (1983) to quantitate PHB in different microorganisms like Rhizobium and japonicum bacteroids. Isotope dilution mass spectrometry was used by Alvarez et al., (2017) to quantify PHB in prokaryotes at microscale level. The gas chromatographic (GC) determination of PHB in microbial cells was first described by Braunegg et al., (1978). NMR techniques have been applied fruitfully to resolve the composition of the hydroxybutyrate units in a copolymer (Bloembergen et al., 1986as determined by NMR, ranged from 0 to $47 \mathrm{~mol} \% / 3$-hy-droxyvalerate (HV; Caballero et al., 1995; Gross et al., 1989). Srienc et al., (1984) used flow cytometry to clearly demonstrate potential advantage of single cell light scattering measurement by flow cytometry for analysis and control of fermentation processes. Flow cytometry cell sorting technology should find significant application in strain improvement and mutant selection. Takeuchi et al., (2016)natural seawaters were cultured in nutrient-rich medium for purple non-sulfur photosynthetic bacteria, and twelve pink- or red-pigmented colonies were picked up. Gas chromatography mass spectrometry analysis revealed that four isolates synthesized PHA at levels ranging from 0.5 to $24.4 \mathrm{wt} \%$ of cell dry weight. The $16 \mathrm{~S}$ ribosomal RNA sequence analysis revealed that one isolate (HM2 isolated pigmented bacteria under nutrient-rich conditions as PHA-producing purple non-sulphur photosynthetic bacteria from natural sea waters. Low cost substrates were used by Takshshi et al., (2017) to produce PHA from selected marine strains. 


\section{SUBSTRATES AND GROWTH CONDITIONS FOR PHB PRODUCTION}

Nutrient limitation directly increases PHB production but high nitrogen state leads to augment biomass growth with no PHB production (Albuquerque et al., 2010). 66\% of PHB on dry weight basis was produced by Pseudomonas sp. when feed on methanol as primary carbon source (Suzuki et al., 1986). Carbon/nitrogen $(\mathrm{C} / \mathrm{N})$ ratio is a very crucial variable to be considered during $\mathrm{PHB}$ production. When $\mathrm{C} / \mathrm{N}$ ratio increased to 28.3, PHB production also increased by 1.8 -folds, where sucrose was carbon source, ammonium sulphate was nitrogen source, optimum $\mathrm{pH}$ of 6.5 , and temperature of $33{ }^{\circ} \mathrm{C}$ were provided in batch culture of Alcaligenes latus ATCC 29713 (Grothe et al., 1999). It was found that decrease in dissolved oxygen content, decreases biomass accumulation and PHB production. Apart from it, Study by 13C NMR spectroscopy showed that feeding strategy greatly affects the monomers compositions and production of PHB produced (Ivanova et al., 2009). HV contents of PHA increased by $8 \%$ when fermented molasses as source of VFAs was fed continuously (Albuquerque et al., 2011). Increase by 4.8 -fold was reported when whey, a dairy waste product rich in sugars, as substrate was fed intermittently with ammonium sulphate in fed-batch culture of Methylobacterium sp. ZP24 under oxygen limiting conditions (Nath et al., 2008). Gumel et al., (2014) suggested that the monomer composition of the PHA ranges from $\mathrm{C} 4$ to $\mathrm{C} 14$, and were strongly influenced by the type of carbon substrate fed. Interestingly, an odd carbon chain length (C7) monomer was also detected when C18:1 was fed. Polymer showed melting temperature $(\mathrm{Tm})$ of $42.0(0.2){ }^{\circ} \mathrm{C}$, glass transition temperature $(\mathrm{Tg})$ of $-1.0(0.2){ }^{\circ} \mathrm{C}$ and endothermic melting enthalpy of fusion (Hf) of $110.3(0.1) \mathrm{J} g-1$. The molecular weight $(\mathrm{Mw})$ range of the polymer was relatively narrow between 55 to $77 \mathrm{kDa}$. PHB output from Methylobacterium SPV-49 was studied byGhatnekar et al., (2002). They studied various carbon sources and found that PHB accumulation was highest when glucose was the carbon source. PHB accumulation was also there when sucrose and lactose was used as carbon source. Sudan black B was used to isolate 37 mutants of Azotobacterchroococcum for PHB production (Parshad et al., 2001). PHB production was maximum with $2 \%$ glucose and $15 \mathrm{mM} / \mathrm{l}$ ammonium acetate at 36 and 48 hours of growth under submerged and stationary culture respectively. They also found that sucrose and commercial sugars were better carbon source than glucose and mannitol as PHB accumulation was higher with sucrose and commercial sugars. Growth culture parameters for R. eutropha NRRL814690 were optimized by Khanna \& Srivastava, (2005b) to reduce PHB production cost. In
48 hours $3.25 \mathrm{~g} / \mathrm{l}$ of biomass was produced with $1.4 \mathrm{~g} / \mathrm{l}$ of PHB concentration and fructose and ammonium sulphate were used as carbon and nitrogen source respectively. Alcaligeneseutrophus MTCCC1285 was used to study the effect of $\mathrm{pH}$ on yields of PHB (Kumar \& Prabakaran, 2006). Two pH levels viz. 6.9 and 8.0 were used to study PHB production. At pH 6.9 the amount of PHB produced was $0.8,0.5,0.4$ and at $\mathrm{pH} 8.0$ it was 1.1 , $0.65,0.55$ and $1.0 \mathrm{~g} / \mathrm{ml}-\mathrm{l}$ in glucose, sago, thippi and molasses substrate based media respectively. Wei et al., (2011) shown that the production of PHB is maximum at $\mathrm{pH} 7.0$ and temperature $30^{\circ} \mathrm{C}$. Operational condition at neutral pH 7 resulted in PHB accumulation up to 25\% of CDW when compared to basic pH 9 (8.5\%) and acidic pH 6 (15\%). Acetic acid and propionic acid mixture in different proportion was used as carbon substrate to enrich the culture with organic load of $8.5 \mathrm{~g} \mathrm{COD} \mathrm{L}^{-1}$ day maintained at pH ranging from 7.7 to 9.5. Enriched culture showed high production rate and yields $(389 \mathrm{mg}$ $\mathrm{PHAg}^{-1}$ of nonpolymeric biomass) in SBR if maintained at $\mathrm{pH}$ of 7.5 with Lampropedia hyalina as dominant bacterial species (Villano et al., 2010). Growth of bacterial strain and PHB production is also determined by agitation rate. Agitation rate of $150-200 \mathrm{rpm}$ is best for PHB production and production decreases as the rate exceeds $200 \mathrm{rpm}$ (Wei et al., 2011). Different agitation rates were opted by different scientists according to the type of microorganism and culture conditions (Castillo et al., 2016; García-Torreiro et al., 2017).

\section{OPTIMIZATION OF CULTURE CONDITIONS FOR MAXIMUM PHB PRODUCTION USING STATISTICAL TOOLS}

Fermentation has to be optimised to increase the yield and productivity of various bioprocesses. Conventionally, one component change was used to optimise fermentation but this is time consuming (Khanna \& Srivastava 2005a). In recent years statistically optimised methods have been used to replace this technique. Pandian et al., (2010)it was suggested that strain SRKP-3 was similar to Bacillus megaterium. A four-factor central composite rotary design (CCRD isolated a gram-positive bacterium SRKP-3 similar to Bacillus megaterium that potentially accumulated polyhydroxyalkanoates (PHAs). A four-factor central composite rotary design (CCRD) was employed to optimize the medium and to find out the interactive effects of four variables, viz. concentrations of dairy waste, rice bran, sea water and $\mathrm{pH}$ on PHB production and a yield of $6.37 \mathrm{~g} / \mathrm{L}$ of PHB dry weight was achieved by the optimized medium at $\mathrm{pH}$ 9. Muralidharan and Radha adopted a two-stage cultivation strategy for PHB production. Culture conditions for Bacillus subtilis MTCC 9763 were optimised 
carbon, $\mathrm{N}_{2}$ source, temperature, $\mathrm{pH}$ and incubation time. $55.0 \mathrm{mg} \mathrm{PHB} / \mathrm{g}$ cell weight was obtained with glucose as carbon source, $17.2 \mathrm{mg} / \mathrm{g}$ cell weight with peptone as $\mathrm{N}_{2}$ source, $\mathrm{pH} 7$ yielded $35.43 \mathrm{mg} / \mathrm{g}$ cell weight and $35^{\circ} \mathrm{C}$ yielded maximum production i.e. $52.2 \mathrm{mg} / \mathrm{g}$ cell weight (Muralidharan \&t Radha, 2014). Batch kinetics can be used for model development, which will make possible simulation of nutrient limited cultivation(s) for over accumulation of PHB (Aswathy 2015).

\section{COST EFFECTIVE AND EXPEDITIOUS PHB PRODUCTION PROTOCOL- NEED OF THE HOUR}

The high cost of PHB production is the major limiting factor for its commercial use. The factors behind the increased cost is the substrate used and downstream processing. This high cost can be reduced by use of cheaper carbon sources. The precursor molecules for PHB production are volatile fatty acids which can be obtained from various sources including municipal waste, banana pseudo stem, spoiled cereals, pea covering, apple pomace, effluents from vegetable oil mills, potato peels, rice bran, groundnut oil molasses, cotton and mustard cake. Lower volatile fatty acids are utilized by several bacteria like A. utrophus, B. megaterium, $P$. oleovorans, $R$. bejjerinckia and Nocardia to produce PHB (Kalia et al., 2000). Various agricultural and dairy wastes have been used to produce PHB with or without ammonium sulphate supplementation. Valentin \& Dennis, (1997) accounted that genetically modified $E$. coli was efficient of using molasses as carbon source to produce PHB. The net dry cell mass, PHB concentration and efficiency of PHB production were $39.5 \mathrm{~g} / \mathrm{l} / \mathrm{h}, 80 \%$, (w/w) and $1 \mathrm{~g} / \mathrm{l} / \mathrm{h}$ respectively. Among all the waste used, anaerobically treated waste gave the maximum PHB production. Kumar et al., (2004)the production of biodegradable plastics using the sludge has been proposed. Storage polymers in bacterial cells can be extracted and used as biodegradable plastics. However, widespread applications have been limited by high production cost. In the present study, activated sludge bacteria in a conventional wastewater treatment system were induced, by controlling the carbon: nitrogen ratio to accumulate storage polymers. Polymer yield increased to a maximum 33\% of biomass (w/w used sludge from waste water treatment plants to produce bioplastic. They found that when C:N ratio was raised from 24 to 144 the polymer yield was increased to a maximum of 33\% of biomass (w/w). Mayeli et al., 2015 used petrochemical wastewater as the source of carbon for the production of polyhydroxyalkanoates (PHA) in an effort to decrease its cost of production. Getachew $\mathrm{Ct}$ Woldesenbet, (2016) isolated Bacillus sp. which can be used for feasible production of PHB using agro-residues especially sugar cane bagasse. These protocols were able to solve two big environmental problems, first were the utilization of industrial waste and second were reduced cost of PHB production.

\section{PHB EXTRACTION AND RETRIEVAL}

In addition to maintenance of pure culture, PHA retrieval process and high substrate cost are some other factors that add to the high cost of PHB production. Several retrieval processes have been looked into and studied, over the past years to develop an economical protocol for large scale PHB production. PHB. Chloroform extraction method was depicted in 1990 (Doi, 1990). Hot chloroform was used to extract PHA in a Soxhlet apparatus and PHA so obtained was sorted from lipids by salting out with $\left(\mathrm{C}_{2} \mathrm{H}_{5}\right)_{2} \mathrm{O}, \mathrm{C}_{6} \mathrm{H}_{14}, \mathrm{CH}_{3} \mathrm{OH}$ or $\mathrm{C}_{2} \mathrm{H}_{5} \mathrm{OH}$. At last, PHA was purified by re-suspending in $\mathrm{CHCl}_{3}$ and by salting out with $\mathrm{C}_{6} \mathrm{H}_{14}$. PHA was retrieved from $R$. eutrophia by digesting with hypochlorite pre-treated with surfactant (Ramsay et al., 1990). Three different chlorinated solvents $\left(\mathrm{CHCl}_{3}, \mathrm{CH}_{2} \mathrm{Cl}_{2}\right.$ and $\left.\mathrm{C}_{2} \mathrm{H}_{4} \mathrm{Cl}_{2}\right)$ were used to retrieve PHA and it was found that biomass pre-treated with acetone was best to retrieve PHA (Ramsay et al., 1994). A system for retrieving PHB from $E$. coli expressing lysozyme gene from T7 demonstrated by (Fidler \& Dennis, 1992). Lysozyme causes the release of PHB granules by penetrating the cells and causing cell lyssis. The cells are harvested and suspended into chelating agents like EDTA at the end of accumulation phase. This leads the release of PHA granules through cell disruption by the activated lysozyme. Dispersion with $\mathrm{NaClO}$ and $\mathrm{CHCl}_{3}$ method was advocated by Hahn et al., 1995. They claimed the removal of almost all of the cellular components from PHA during hypochlorite digestion (Hahn et al., 1995; Gamal et al., 2013).

\section{MOLECULAR CHARACTERIZATION OF PHB GENES FOR THE MAXIMUM PHB PRODUCTION}

The introduction of molecular techniques has boosted the biopolymer research that has enabled to understand various regulations in the PHA synthesis in vivo to produce PHB in an efficient way. The isolation of the genes involved in PHA biosynthesis resulted in heterologous expression of the cloned PHA genes in suitable host organisms and metabolic engineering for higher and safer productivity. Different strategies have been applied to identify and isolate PHA biosynthesis genes from various natural microorganisms. Colony PCR and seminested PCR techniques were used by Sheu et al., (2000), to screen polyhydroxyalkanoates (PHAs) producers, isolated from different environments. Multiple sequence alignment was used to design degenerate primers for use in PCR to identify PHA synthase genes. For Ralstonia 
eutropha the sensitivity limits of colony PCR were $1 \mathrm{x}$ $10^{5}$ and the results advise the use of this PCR in identification of PHB fabricators from environment. Bacterial strains isolated from varying environment were studied for the presence of PHA synthase using colony PCR (Sujatha et al., 2005)totally biodegradable plastics. The cost of these biopolymers is $25 \%$ more than the synthetic polymers that prevents their usage in wider range of applications. In order to reduce the cost, much effort has been made to screen the promising indigenous PHB producing strain in the present study. As a first step, among thirty scl (Short-Chain-Length.

Genomic DNA isolated using Sambrook et al., (1989) protocol was used as the template to carry out colony PCR using three primers phacF1, phaF2 and phaCR4 to detect PHA synthase genes. The PHA operon was first characterized in $R$. eutropha by Peoples \& Sinskey, (1989) that made available the use of heterologous probe to isolate PHA genes from a number of organisms. Most of the PHA genes reported are isolated from various bacteria through constructing genomic DNA library and screening with probes. Rehm \& Steinbüchel, (1999) cloned and characterized the polyhydroxyalkanoic acid synthase gene from Chromobacteriumviolaceum (phaCCv). A 6.3$\mathrm{kb}$ BamHI fragment was found to contain both phaCCv and the polyhydroxyalkanoic acid (PHA)-specific 3-keto thiolase (phaACv). E. coli strains harboring this fragment produced significant levels of PHA synthase and 3-keto thiolase. Three genes are considered to be essential in the PHB biosynthetic pathway are phbA ( $\beta$-keto thiolase), phbB (acetoacetyl coenzyme A reductase) and phbC (PHB synthase), were identified in Azospirillumbrasilenses Sp7. The phbA, -B, and -C genes were found to be linked together and located on the chromosome. In order to reduce the cost, much effort has been made to screen the promising indigenous PHB producing strain Pseudomonas LCD-5. This strain was selected for further characterization (Sujatha et al., 2005).

Preethi et al., (2012) isolated, characterized and screened PHA producing bacteria from soil by Nile Blue staining method. Screened organisms were subjected to fermentation with glucose as carbon source and lowcost raw material like jambul seed. The strain SPY-1 showed higher PHA accumulation when compared to the other strains and the reference strain $R$. eutropha. Berekaa, (2012) designed and applied a pair of specific PCR primers for genotypic detection of phaC synthase gene in eight strains. Approximately, 760 bp DNA fragment was successfully amplified in the eight strains. The sequence showed 99\% identity to phaC gene for polyhydroxyalkanoate synthase of many $B$. megaterium strains deposited in Genbank. While, showed 73\% and 72\% identity to synthases of Bacillus mycoides and Bacillus sp. INT005, respectively. The PHB synthases obtained from Chromobactariumvoilaceum belongs to class 1 PHA synthases. This study seeks to investigate the structural and functional properties of PHB synthase ( $p h a \mathrm{C})$ by predicting its three-dimensional structure using bioinformatics methods (Blessia et al., 2012; Bresan et al., 2016).

\section{PHB PRODUCTION IN ALTERNATIVE HOST (HIGHER ORGANISMS)}

PHB biosynthesis studies from yeast and insects can be used to transform plants for PHB accumulation. PHB synthase gene from $R$. eutropha expressed in S. cerevisiae has been used to manifestate PHB biosynthesis (Leaf et $a l$., 1996). A yeast plasmid was constructed using the phaCRe gene from $R$. eutropha, which enabled functional synthase enzyme expression in $S$. cerevisiae. A very less amount of PHB (0.5\%) accumulation was there in these cells (Poirier et al., 2005). Spodoptera frugiperda cell lines accumulated PHB upon simultaneous transfection with mutant rat fatty acid synthase and PHB synthase from $R$. eutropha. One liter of cultured cells produced $1 \mathrm{mg}$ of PHB (Williams et al., 1996). Expressing PHA biosynthesis genes in plants is need of hour. PHA biosynthesis genes have been expressed in A. thaliana and several agricultural crops like B. napus, G. hirsutum, N. tabacum, S. tuberosum and Z. mays (John \& Keller, 1996; Hahn et al., 1999;retained their catalytic activity, and reacted with peroxisomally available precursors because PHB synthesis in transgenic plant cells was localized to peroxisomes. Up to $2 \mathrm{mg} / \mathrm{g}$ fresh weight PHB was produced in suspension cultures of Black Mexican Sweet maize cells after biolistic transformation with three peroxisomally targeted bacterial genes. An equilibrium effect is proposed to explain the unexpected existence of (R Houmiel et al., 19991994, Proc Natl Acad Sci USA 91: 12760-12764; Nakashita et al., 1999; Steinbüchel, 2001; Bohmert-Tatarey et al., 2011; Petrasovits et al., 2012).

\section{TACTICS TO AMEND PHB PRODUCTION}

Generally, non-genetically engineered bacterial strains are used in PHB production systems but efforts have been made to enhance PHB production through genetic engineering. Most the modifications include changes in regulatory systems and transgenic favouring PHB synthesis. Deeper insights into regulatory pathways have led to the construction of mutants with improved PHB production. Moreover, few transgenic strains have exhibited to produce ample of PHB for mass scale production. The growth in fermentation approaches has also exhibited hope for improvement. In general, the exploitation of recombinant bacterial strains in combination with continuous and multi-stage fermentation techniques 
and cheaper raw material could be a particular way to improve PHB production at mass scale.

\section{APPLICATIONS OF PHB AND CURRENT COMMERCIAL STATUS OF BIOPLASTICS}

Apart from the common applications such as production of poly bags, receptacles, instrumentation and decanters for soft drinks and dairy products, drugs can be made with the help of bioplastic. With the advancement of knowledge and technology, this biomaterial will mediate the manufacturing of products like cellular phones, cameras, medical equipments and automobile parts. The application of bioplastics in tissue engineering as a scaffolding material is presently gaining interest (Misra et al., 2006; Luklinska \& Bonfield, 1997). They can be a replacement of body devices as they are immunologically inert and degraded slowly inside human tissue. These are used by scientist to make medical devices like artificial bone implants, pacemaker, valves and bio-resorbable surgical sutures (Fedorov et al., 2005; Rossiiskaia akademiia nauk et al., 1995). They can also be used as drug delivery agents for slow and constant release of drug inside the body for a longer time period (Chen \& Wu, 2005; Grage et al., 2009).

Studies related to use of bioplastics in medical science are in preliminary phase and a lot of improvements have to be done. PHB based microcapsules have many applications in pharmacology such as a controlled release of water soluble drugs, various types of proteins, peptides and nucleic acids. Controlled release Methylene green drug is encapsulated with PHB microcapsules is an example of biodegradable microcapsules (Bonartsev et al., 2007). Since the large-scale production of bioplastics at industrial scale is very expensive so it has not been used extensively. During 20th century, the bioplastics production was mainly dominated by the developed countries like North America, Japan, and Western Europe etc. Bioplastic market is at its initial stages of development in South East Asia. In the recent years biopolymers are becoming a crucial part of Food Science and Technology, Nanotechnology, Chemical Sciences, Medical and Agricultural Sciences. Nearly $20 \%$ increase in bioplastic production was observed in this year. The production of bioplastic has increased for 1.5 million tons in 2011 to 6 million tons in 2016 (fivefold increase). By 2020 bioplastic production will touch a mark of 12 million tons (International Conference and Exhibition on Biopolymers and Bioplastics, 2015).

\section{CONCLUSION AND FUTURE OUTLOOK}

As the public concerns are increasing about the hiking cost of petroleum and damaging effects of the petro- leum based plastic materials in the environment, this work was focused on the production of biodegradable plastics polyhydroxybutyrate from low-cost and easily available raw materials. PHB is a biopolymer which can be completely degraded into $\mathrm{H}_{2} \mathrm{O}$ and $\mathrm{CO}_{2}$ by soil microorganisms. This review paper was aimed to provide an overview of bacterial polyhydroxybutyrate. This review covers the characterization, biosynthesis, identification and quantification, biotechnological strategies for improvement of PHB production, and its application in different fields. Presently their production is pricey and laborious, so profit making from bioplastics is at initial stages. Advance investigations on high PHB producing novel bacteria novel bacteria, recombinant microbial strains, mixed cultures, competent fermentations, recovery, purification and the use of low-cost and economical substrates like Agri-byproducts can significantly help to trim down the production cost.

\section{REFERENCES}

Albuquerque M.G.E, Martino V., Pollet E., Avérous L. and Reis M.A.M. (2011). Mixed culture polyhydroxyalkanoate (PHA) production from volatile fatty acid (VFA)-rich streams: Effect of substrate composition and feeding regime on PHA productivity, composition and properties. Journal of Biotechnology. 151: 66-76.

Albuquerque M.G.E., Torres C.A.V. and Reis M.A.M. (2010). Polyhydroxyalkanoate (PHA) production by a mixed microbial culture using sugar molasses: Effect of the influent substrate concentration on culture selection. Water Research. 44:34193433.

Alvarez M.I.V., ten Pierick A., van Dam P.T.N., Seifar R.M., van Loosdrecht M.C.M. and Wahl S.A. (2017). Microscale quantitative analysis of polyhyroxybutyrate in prokaryotes using IDMS. Metabolites. 7: 1-8.

Andrady A.L. (1994). Assessment of environmental biodegradation of synthetic polymers. Journal of Macromolecular Science. 34: 25-76.

Andrady A.L. (2015a). Degradation of plastics in the environment. In Plastics and Environmental Sustainability. Hoboken, New Jersey: John Wiley \& Sons, pp. 145-184.

Asrar J. and Gruys K.J. (2002). Biodegradable polymer (biopolh). In Biopolymers, Volume 4: Polyesters III - Applications and Commercial Products. Edited by Y. Doi \&t A. Steinbu"chel. Weinheim: Wiley-VCH, pp. 53-90.

Aswathy M. (2015). Production of bio-plastics (Polyhydroxy Butyrate) from industrial effluents using batch and two stage batch studies. Indian Journal of Science and Technology. 8(32): 1-6.

Atlas R.M. and Bartha R. (1993). Microbial ecology: fundamentals and applications 3rd ed. Benjamin/Cummings Pub. Co, Redwood City.

Barth M., Honak A., Oeser T., Wei R., Belisário-Ferrari M.R. and Then J. (2016). A dual enzyme system composed of a 
polyester hydrolase and a carboxylesterase enhances the biocatalytic degradation of polyethylene terephthalate films. Biotechnology Journal. 11: 1082-1087.

Berekaa M.M. (2012). Genotypic detection of polyhydroxyalkanoate-producing bacilli and characterization of phaC synthase of Bacillus sp. SW1-2. Life Science Journal. 9: 518-529.

Bharti S.N. and Swetha G. (2016). Need for bioplastics and role of biopolymer PHB: A Short Review. Journal of Petroleum and Environmental Biotechnology. 7(2): 2-4.

Blessia T.F., Sharmila D.J.S., Samian M.R., Arsad H. and Jamil N.F. (2012). Structural analysis and molecular dynamics study of phb synthase.International Research Journal of Pharmacy. 3: $251-256$

Bloembergen S., Holden D., Hamer G.K., Bluhm T.L. and Marchessault R.H. (1986). Studies of composition and crystallinity of bacterial poly( $\beta$-hydroxybutyrate-co- $\beta$-hydroxyvalerate). Macromolecules. 19: 2865-2871.

Bohmert-Tatarev K., Mcavoy S., Daughtry S., Peoples O.P. and Snell K.D. (2011). High levels of bioplastic are produced in fertile transplastomic tobacco plants engineered with a synthetic operon for the production of polyhydroxybutyrate. Plant Physiology. 155: 1690-1708.

Bonartsev A.P., Myshkina V.L., Nikolaeva D.A., Furina E.K., Makhina T.A., Livshits V.A., Boskhomdzhiev A.P., Ivanov E.A., Iordanskii A.L. and Bonartseva G.A. (2007). Biosynthesis, biodegradation, and application of poly(3-hydroxybutyrate) and its copolymers-natural polyesters produced by diazotrophic bacteria. In Communicating Current Research and Educational Topics and Trends in Applied Microbiology; Mendez-Vilas, A., Ed.; pp 295-307.

Braunegg G., Bona R. and Koller M. (2004). Sustainable polymer production. Polymer-Plastics Technology and Engineering. 43: 1779-1793.

Braunegg G., Sonnleitner B. and Lafferty R.M. (1978). A rapid gas chromatographic method for the determination of poly- $\beta$ hydroxybutyric acid in microbial biomass. European Journal of Applied Microbiology and Biotechnology. 6: 29-37.

Bresan S., Sznajder A., Hauf W., Forchhammer K., Pfeiffer D. and Jendrossek D. (2016). Polyhydroxyalkanoate (PHA) granules have no phospholipids. Scientific Reports. 6: 1-13.

Caballero K.P., Karel S.F. and Register R.A. (1995). Biosynthesis and characterization of hydroxybutyrate-hydroxycaproate copolymers. International Journal of Biological Macromolecules. 17: 86-92.

Cesário M.T., Raposo R.S., de Almeida M.C.M.D., van Keulen F., Ferreira, B.S. and da Fonseca M.M.R. (2014). Enhanced bioproduction of poly-3-hydroxybutyrate from wheat straw lignocellulosic hydrolysates. New Biotechnology. 31: 104-113.

Castillo T., Flores C., Segura D., Espín G., Sanguino J., Cabrera E., Barreto J., Díaz-Barrera A. and Peña C. (2016). Production of polyhydroxybutyrate (PHB) of high and ultra-high molecular weight by Azotobacter vinelandii in batch and fed-batch cultures. Journal of Chemical Technology and Biotechnology. 92(7): 1809-1816.
Chandani, N., Mazumder P.B. and Bhattacharjee A. (2018). Biosynthesis of biodegradable polymer by a potent soil bacterium from a stress-prone environment. Journal of Applied Biology Et Biotechnology. 6(2): 54-60.

Chanprateep S. (2010). Current trends in biodegradable polyhydroxyalkanoates. Journal of Bioscience and Bioengineering. 110: 621-632.

Chen G-Q. (2010). Plastics Completely Synthesized by Bacteria: Polyhydroxyalkanoates. p. 17-37.

Chen G-Q. and Wu Q. (2005). The application of polyhydroxyalkanoates as tissue engineering materials. Biomaterials. 26: 6565-6578.

Cheng J., Pinnell L., Engel K., Neufeld J.D. and Charles T.C. (2014). Versatile broad-host-range cosmids for construction of high quality metagenomic libraries. Journal of Microbiological Methods. 99: 27-34.

Choi G.G., Kim H.W. and Rhee YH. (2004). Enzymatic and non-enzymatic degradation of poly (3-hydroxybutyrate-co3-hydroxyvalerate) copolyesters produced by Alcaligenes sp. MT-16. Journal of Microbiology. 42: 346-52.

Doi Y. (1990). Microbial polyesters. Wiley-VCH Verlag GmbH Et Co. KGaA, Weinheim, Germany.

Fedorov M.B., Vikhoreva G.A., Kil'deeva N.R., Maslikova A.N., Bonartseva G.A. and Gal'braikh L.S. (2005). Modeling of surface modification of sewing thread. Fibre Chemistry. 37: 441446.

Fidler S. and Dennis D. (1992). Polyhydroxyalkanoate production in recombinant Escherichia coli. FEMS Microbiology Reviews. 9: 231-235.

Gamal R.F., Abdelhasdy H.M., Khodiar T.A., El-Tayeb T.S., Hassan E.A. and Aboutaleb K.A. (2013). Semi-scale production of PHAs from waste frying oil by Pseudomonas fluorecens S48. Brazilian Journal of Microbiology. 44(2): 539-549.

Galehdari H., Alaee S. and Mirzaee M. (2009). Cloning of poly (3-hydroxybutyrate) synthesis genes from Azotobacter vinelandii into Escherichia coli. Jundishapur Journal of Microbiology. 2: 31-35.

Galia MB. (2010). Isolation and analysis of storage compounds. In: Timmis KN, Editor. Handbook of hydrocarbon and lipid microbiology. Berlin: Springer, pp. 3725-41.

García-Torreiro M., Lopez-Aberlairs M., Lu-Chau T.A. and Lema J.M. (2017). Application of flow cytometry for monitoring the production of poly(3-hydroxybutyrate) by Halomonas boliviensis. Biotechnology Progress. 33: 276-284.

Gasser I., Müller H. and Berg G. (2009). Ecology and characterization of polyhydroxyalkanoate-producing microorganisms on and in plants. FEMS Microbiology Ecology. 70: 142-150.

Getachew A. and Woldesenbet F. (2016). Production of biodegradable plastic by polyhydroxybutyrate (PHB) accumulating bacteria using low cost agricultural waste material. BMC Research Notes. 9: 509.

Ghatnekar M.S., Pai J.S. and Ganesh M. (2002). Production and recovery of poly-3-hydroxy-butyrate from Methylo bacterium 
sp V49. Journal of Chemical Technology and Biotechnology. 77: 444-448.

Grage K., Jahns A.C., Parlane N., Palanisamy R., Rasiah I.A., Atwood J.A. andBernd H.A.R.(2009). Bacterial Polyhydroxyalkanoate Granules: Biogenesis, Structure, and Potential Use as Nano-/Micro-Beads in Biotechnological and Biomedical Applications. Biomacromolecules. 10: 660-669.

Gross R.A., DeMello C., Lenz R.W., Brandl H. and Fuller R.C. (1989). The biosynthesis and characterization of poly( $\beta$ hydroxyalkanoates) produced by Pseudomonas oleovorans. Macromolecules. 22: 1106-1115.

Grothe E., Moo-Young M. and Chisti Y. (1999). Fermentation optimization for the production of poly $(\beta$-hydroxybutyric acid) microbial thermoplastic. Enzyme and Microbial Technology. 25: 132-141.

Gumel A.M., Annuar M.S.M. and Heidelberg T. (2014). Growth kinetics, effect of carbon substrate in biosynthesis of mcl-PHA by Pseudomonas putida Bet001. Brazilian Journal of Microbiology. 45: 427-38.

Gurieff N. and Lant P. (2007). Comparative life cycle assessment and financial analysis of mixed culture polyhydroxyalkanoates production. Bioresource Technology. 98:3393-403.

Haas C., Steinwandter V., de Apodaca E.D., Maestro Madurga B., Smerilli M., Dietrich T. and Neureiter M. (2015). Production of PHB from chicory roots-comparison of three Cupriavidus necator strains. Chemical and Biochemical Engineering Quarterly. 29: 99-112.

Hahn S.K., Chang Y.K. and Lee S.Y. (1995). Recovery and characterization of poly(3-hydroxybutyric acid) synthesized in Alcaligenes eutrophus and recombinant Escherichia coli. Applied and Environmental Microbiology. 61: 34-9.

Hahn J.J., Eschenlauer A.C., Sleytr U.B., Somers D.A. and Srienc F. (1999). Peroxisomes as sites for synthesis of polyhydroxyalkanoates in transgenic plants. Biotechnology Progress. 15: 1053-1057.

Hamieh A., Olama Z. and Holail H. (2015). Microbial production of polyhydroxybutyrate, a biodegradable plastic using agro-industrial waste products. Global Advanced Research Journal of Microbiology. 2(3): 54-64.

Hartman TL. (1940). The use of Sudan Black B as a bacterial fat stain. Stain Technology. 15:23-28.

Higuchi-Takeuchi M., Morisaki K. and Numata K. (2016). A screening method for the isolation of polyhydroxyalkanoateproducing purple non-sulfur photosynthetic bacteria from natural seawater. Frontiers in Microbiology. 7: 1-7.

Hong K., Sun S., Tian W., Chen G.Q. and Huang W. (1999). A rapid method for detecting bacterial polyhydroxyalkanoates in intact cells by Fourier transform infrared spectroscopy. Applied Microbiology and Biotechnology. 51: 523-526.

Houmiel K.L., Slater S., Broyles D., Casagrande L., Colburn S., Gonzalez K., Mitsky T.A., Reiser S.E., Shah D., Taylor N.B., Tran M., Valentin H.E. and Gruys K.J.(1999). Poly(beta-hydroxybutyrate) production in oilseed leukoplasts of Brassica napus. Planta. 209: 547-50.
Hrabak 0. (1992). Industrial production of poly- $\beta$ hydroxybutyrate. FEMS Microbiology Letters. 103: 251255.

Ivanova G., Serafım L.S., Lemos P.C., Ramos A.M., Reis M.A.M. and Cabrita E.J. (2009). Influence of feeding strategies of mixed microbial cultures on the chemical composition and microstructure of copolyesters $\mathrm{P}(3 \mathrm{HB}-\mathrm{co}-3 \mathrm{HV})$ analyzed by NMR and statistical analysis. Magnetic Resonance in Chemistry. 47: 497-504.

Jendrossek D. and Handrick R. (2002). Microbial degradation of polyhydroxyalkanoates. Annual Review of Microbiology. 56: 403-32.

John M.E. and Keller G. (1996). Metabolic pathway engineering in cotton: biosynthesis of polyhydroxybutyrate in fiber cells. Proceedings of National Academy of Sciences U S A. 93:12768-12773.

Jüttner R.R., Lafferty R.M. and Knackmuss H. (1975). A Simple Method for the Determination of Poly- $\beta$-Hydroxybutyric Acid in Microbial Biomass. European Journal of Applied Microbiology. 237: 233-237.

Kalia V.C., Raizada N. and Sonakya V. (2000). Bioplastics. Journal of Scientific \&t Industrial Research. 59: 433-445.

Karr D.B., Waters J.K. and Emerich D.W. (1983). Analysis of poly- $\beta$-hydroxybutyrate in Rhizobium japonicum bacteroids by ion-exclusion high-pressure liquid chromatography and UV detection. Applied and Environmental Microbiology. 46: 1339-1344.

Khanna S. and Srivastava A.K. (2005). Statistical media optimization studies for growth and PHB production by Ralstonia eutropha. Process Biochemistry. 40: 2173-2182.

Khanna S. and Srivastava A.K. (2005). Recent advances in microbial polyhydroxyalkanoates. Process Biochemistry. 40:607-619.

Kumar B.S. and Prabakaran G. (2006). Production of PHB (bioplastics) using bio-effluent as substrate by Alcaligens eutrophus. Indian Journal of Biotechnology. 5: 76-79.

Leaf T.A., Peterson M.S., Stoup S.K., Somers D. and Srienc F. (1996). Saccharomyces cerevisiae expressing bacterial polyhydroxybutyrate synthase produces poly-3-hydroxybutyrate. Microbiology. 142: 1169-1180.

Ling S.C., Tsuge T. and Sudesh K. (2011). Biosynthesis of novel polyhydroxyalkanoate containing 3-hydroxy-4-methylvalerate by Chromobacterium sp. USM2. Journal of Applied Microbiology. 111: 559-571.

Liu X-J., Zhang J., Hong P-H. and Li Z-J. (2016). Microbial production and characterization of poly-3-hydroxybutyrate by Neptunomonas antarctica. PeerJ. 4:e2291.

Luklinska Z.B. and Bonfield W. (1997). Morphology and ultrastructure of the interface between hydroxyapatite-polyhydroxybutyrate composite implant and bone. Journal of Materials Science Materials in Medicine. 8: 379-383.

Madison L.L. and Huisman G.W. (1999). Metabolic engineering of poly(3-hydroxyalkanoates): from DNA to plastic. Microbiology and Molecular Biology Reviews. 63: 21-53. 
Mayeli N., Motamedi H., Heidarizadeh F., Mayeli N., Motamedi H. and Heidarizadeh F. (2015). Production of Polyhydroxybutyrate by Bacillus axaraqunsis BIPC01 using Petrochemical Wastewater as Carbon Source. Brazilian Archives of Biology and Technology. 58: 643-650.

Misra S.K., Valappil S.P., Roy I. and Boccaccini A.R. (2006). Polyhydroxyalkanoate (PHA)/Inorganic Phase Composites for Tissue Engineering Applications. Biomacromolecules. 7: 2249-2258.

Mueller R.J. (2006). Biological degradation of synthetic polyesters-enzymes as potential catalysts for polyester recycling. Process Biochemistry. 41: 2124-2128.

Muralidharan R. and Radha K.V. (2014). Growth and biological production of polyhydroxy butyrate (PHB) by Bacillus megaterium MTCC 8075. Chemical, Biological and Physical Sciences. 4: 1271-1279.

Nakashita H., Arai Y., Yoshioka K., Fukui T., Doi Y., Usami R., Horikoshi K. andYamaguchi I. (1999). Production of biodegradable polyester by a transgenic tobacco. Bioscience, Biotechnology, and Biochemistry. 63: 870-4.

Nath A., Dixit M., Bandiya A., Chavda S. and Desai A.J. (2008). Enhanced PHB production and scale up studies using cheese whey in fed batch culture of Methylobacterium sp. ZP24. Bioresource Technology. 99: 5749-5755.

Ng L.M. and Sudesh K. (2016). Identification of a new polyhydroxyalkanoate (PHA) producer Aquitalea sp. USM4 (JCM 19919) and characterization of its PHA synthase. Journal of Bioscience and Bioengineering. 122: 550-557.

Nielsen C., Rahman A., Ur Rehman A., Walsh M.K. and Miller C.D. (2017). Food waste conversion to microbial polyhydroxyalkanoates. Microbial Biotechnology. 10: 1338-1352.

Nielsen J.L., Kragelund C., Nielsen P.H. (2010). Bioremediation. Humana Press, Totowa, NJ.

Obruca S., Sedlacek P., Krzyzanek V., Mravec F., Hrubanova K., Samek 0., Kucera D., Benesova P. and Marova I.(2016). Accumulation of poly(3-hydroxybutyrate) helps bacterial cells to survive freezing. PLoS One. 11: 1-16.

Ostle A.G. and Holt J.G. (1982). Nile Blue-a as a Fluorescent Stain for Poly-Beta-Hydroxybutyrate. Applied and Environmental Microbiology. 44: 238-241.

Parshad J., Suneja S., Kukreja K. and Lakshminarayana K. (2001). Poly-3-hydroxybutyrate production by Azotobacter chroococcum. Folia Microbiol (Praha). 46: 315-20.

Peoples O.P. and Sinskey A.J. (1989). Poly-beta-hydroxybutyrate (PHB) biosynthesis in Alcaligenes eutrophus H16. Identification and characterization of the PHB polymerase gene (phbC). Journal of Biological Chemistry. 264: 15298-303.

Petrasovits L.A., Zhao L., mcqualter R.B., Snell K.D., Somleva M.N., Patterson N.A., Nielsen L.K. and Brumbley S.M. (2012). Enhanced polyhydroxybutyrate production in transgenic sugarcane. Plant Biotechnology Journal. 10(5): 569-78.

Poirier Y., Gruys K.J., Poirier Y. and Gruys K.J. (2005). Production of Polyhydroxyalkanoates (PHAs) in Transgenic Plants, p. In Doi, Y, Steinbüchel, A (eds.), Biopolymers Online. WileyVCH Verlag GmbH \& Co. KGaA, Weinheim, Germany.
Preethi R., Sasikala P. and Aravind J. (2012). Microbial production of polyhydroxyalkanoate (PHA) utilizing fruit waste as a substrate. Resourece Biotechnology. 3: 61-69.

RamKumar Pandian S., Deepak V., Kalishwaralal K., Rameshkumar N., Jeyaraj M. and Gurunathan S. (2010). Optimization and fed-batch production of PHB utilizing dairy waste and sea water as nutrient sources by Bacillus megaterium SRKP-3. Bioresource Technology. 101: 705-711.

Ramsay J.A., Berger E., Ramsay B.A. and Chavarie C. (1990). Recovery of poly-3-hydroxyalkanoic acid granules by a surfactant-hypochlorite treatment. Biotechnology Techniques. 4: 221-226.

Ramsay J.A., Berger E., Voyer R., Chavarie C. and Ramsay BA. (1994). Extraction of poly-3-hydroxybutyrate using chlorinated solvents. Biotechnology Techniques. 8: 589-594.

Rehm B.H.A. and Steinbüchel A. (1999). Biochemical and genetic analysis of PHA synthases and other proteins required for PHA synthesis. International Journal of Biological Macromolecules. 25: 3-19.

Rossiiskaia A.N. A.V., Dubinsky V.A., Nekrasov Y.P., Bonartseva G.A., Stamm M. and Antipov E.M. (1995). Polymer science. Series B. MAIK Nauka/Interperiodica Pub.

Sambrook J., Fritsch E.F. and Maniatis T. (1989). Molecular cloning : a laboratory manual. Cold Spring Harbor Laboratory.

Sasidharan R.S., Bhat S.G. and Chandrasekaran M. (2016). Amplification and sequence analysis of phaC gene of polyhydroxybutyrate producing Vibrio azureus BTKB33 isolated from marine sediments. Annals of Microbiology. 66: 299-306.

Senior P.J. and Dawes E. (1973). The regulation of poly-betahydroxybutyrate metabolism in Azotobacter beijerinckii. The Biochemical Journal. 134: 225-238.

Sharma P.,Munir R., Blunt W., Dartiailh C., Cheng J., Charles T.C. andLevin D.B. (2017). Synthesis and Physical Properties of Polyhydroxyalkanoate Polymers with Different Monomer Compositions by Recombinant Pseudomonas putida LS46 Expressing a Novel PHA SYNTHASE (PhaC116) Enzyme. Applied Sciences. 7: 242.

Sheu D.S., Wang Y.T. and Lee C.Y. (2000). Rapid detection of polyhydroxyalkanoate accumulating bacteria isolated from the environment by colony PCR. Microbiology. 146: 20192025.

Spiekermann P., Rehm B.H., Kalscheuer R., Baumeister D. and Steinbüchel A. (1999). A sensitive, viable-colony staining method using Nile red for direct screening of bacteria that accumulate polyhydroxyalkanoic acids and other lipid storage compounds. Archives of microbiology. 171: 73-80.

Srienc F., Arnold B. and Bailey J.E. (1984). Characterization of Intracellular Accumulation of Poly-3-Hydroxybutyrate (PHB) in Individual Cells of Alcaligenes eutrophus HI6 by Flow Cytometry. Biotechnology and Bioengineering. 26: 982-987.

Steinbüchel A. (1991). Polyhydroxyalkanoic acids. In Biomaterials. Palgrave Macmillan UK, London, p. 123-213.

Steinbüchel A. (2001). Perspectives for Biotechnological Production and Utilization of Biopolymers: Metabolic Engineering 
of Polyhydroxyalkanoate Biosynthesis Pathways as a Successful Example. Macromolecular Bioscience. 1: 1-24.

Sujatha K., Shenbagarathai R. and Mahalakshmi A. (2005). Analysis of PCR products for PHB production in indigenous Pseudomonas sp. LDC-5. Indian Journal of Biotechnology. 4: 323-335.

Suresh Kumar M., Mudliar S.N., Reddy K.M.K. and Chakrabarti T. (2004). Production of biodegradable plastics from activated sludge generated from a food processing industrial wastewater treatment plant. Bioresource Technology. 95: 327-330.

Suzuki T., Yamane T. and Shimizu S. (1986). Mass production of poly- $\beta$-hydroxybutyric acid by fully automatic fed-batch culture of methylotroph. Applied Microbiology and Biotechnology. 23: 322-329.

Takshashi R.Y.U., Castilho N.A.S., Silva M.A.C.D., Miotto M.C. and Lima A.O.S. (2017). Prospecting for marine bacteria for polyhydroxyalkanoate production on low-cost substrates. Bioengineering. 4: 1-13.

Tokiwa Y., Calabia B., Ugwu C., and Aiba S. (2009). Biodegradability of plastics. International Journal of Molecular Sciences. 10(9): 3722-3742.

Valentin H.E. and Dennis D. (1997). Production of poly(3hydroxybutyrate-co-4-hydroxybutyrate) in recombinant Escherichia coli grown on glucose. Journal of Biotechnology. 58:33-8.

Villano M., Beccari M., Dionisi D., Lampis S., Miccheli A., Vallini G. andMajone M. (2010). Effect of pH on the production of bacterial polyhydroxyalkanoates by mixed cultures enriched under periodic feeding. Process Biochemistry. 45:714-723.

Vinet L. and Zhedanov A. (2010). A “missing” family of classical orthogonal polynomials. Microbiology Reviews. 54:450472.

Wei Y.H., Chen W.C., Wu H.S. and Janarthanan O.M. (2011). Biodegradable and biocompatible biomaterial, polyhydroxybutyrate, produced by an Indigenous Vibrio $s p$. BM-1 isolated from marine environment. Marine Drugs. 9: 615-624.

Wei R. and Zimmermann W. (2017). Microbial enzymes for the recycling of recalcitrant petroleum-based plastics: how far are we? Microbial Biotechnology. 10(6): 1308-1322.

Williams M.D., Rahn J.A., Sherman D.H., Williams M.D., Rahn J.A. and Sherman D.H. (1996). Production of a polyhydroxyalkanoate biopolymer in insect cells with a modified eucaryotic fatty acid synthase. Applied and Environmental Microbiology. 62: $2540-2546$.

Williamson D.H. and Wilkinson J.F. (1958). The Isolation and Estimation of the Poly- $\beta$-hydroxy- butyrate Inclusions of Bacillus species. Jouurnal of General Microbiology. 19:198-209.

Zheng Y., Yanful E.K. and Bassi A.S. (2005). A review of plastic waste biodegradation. Critical Reviews in Biotechnology. 25: 243-250.

Zhu S.W., Fang Z.Y., Jiang H.Y. and Cheng BJ. (2010). Molecular and functional analysis of the poly- $\beta$-hydroxybutyrate biosynthesis operon of Pseudomonas sp BJ-1. Genetics and Molecular Research. 9:2349-2356. 